and it grows very rapidly, which for some purposes is a great advantage. The large litters are useful, for they provide plenty of animals for experimental purposes and for controls.

'La solution d'un problème physiologique ou pathologique résulte uniquement d'un choix plus convenable du sujet de l'expérience, qui rend le résultat plus clair ou plus probant' (Bernard, I865). I think our choice of the pig has on the whole been a happy one.

\title{
REFERENCES
}

Bernard, M. C. (I865). Introduction à l'Étude de la Médicine Expérimentale. Paris: J. B. Baillière et Fils. Edwards, W. F. (1824). De l'Influence des Agents Physiques sur la Vie. Paris: Crochard.

Edwards, W. F. (1832). On the Influence of Physical Agents on Life. (Translated from the French by Dr Hodgkin and Dr Fisher.) London: Highley.

Glauser, E. M., McCance, R. A. \& Widdowson, E. M. (1962). F. Physiol. r6r, 3 I 3.

Goodwin, R. F. W. (1957). F. Physiol. 136, 208.

Harvey, W. (165I). De Generatione Animalium. Translated by Willis, R. (1847). The Works of William Harvey. London: Sydenham Society.

McCance, R. A. \& Widdowson, E. M. (1954). Arch. Dis. Childh. 29, 488.

McCance, R. A. \& Widdowson, E. M. (1956). F. Physiol. r33, 373.

McCance, R. A. \& Widdowson, E. M. (1957). Acta paediat., Uppsala, 46, 337.

McCance, R. A. \& Widdowson, E. M. (1958). F. Physiol. 14r, 8r.

McCance, R. A. \& Widdowson, E. M. (1959). F. Physiol. 147, 124.

McCance, R. A. \& Young, W. F. (1940-1). J. Physiol. 99, 265.

Mann, T. P. \& Elliott, R. I. K. (I957). Lancet, i, 229.

Mayow, J. (r668). Quoted by Parsons (1950).

Nicolopoulos, D. A. \& Smith, C. A. (r960). Amer. F. Dis. Child. roo, 6rg.

Parsons, L. (1950). The Influence of Harvey and his Contemporaries on Paediatrics. The Harveian Oration, 1950. London: Headley Brothers Ltd.

Slater, J. E. (1961). Brit. F. Nutr. 15,83.

Usher, R. H. (1960). Amer. F. Dis. Child. roo, 485 .

Widdowson, E. M. (1957). Proc. Nutr. Soc. r6, i 18.

Young, W. F. \& McCance, R. A. (1942). Arch. Dis. Childh. 17, 65.

\section{Is a big baby healthy?}

\section{By R. C. Mac KeIth, Guy's Hospital, London, S.E.x}

'An adequate understanding is necessary of the way in which habitual diet may determine in part the development of constitution in an individual since such an understanding underlies an approach to the consideration of some diseases of multiple and uncertain aetiology developing in middle life. This group of diseases includes such important degenerative diseases as atherosclerosis, cancer and hypertension. At earlier ages it may include such disorders as allergy, anaphylaxis and the rheumatic, rheumatoid and collagen disorders. The claim is not lightly made. All will agree that the diseases mentioned are of uncertain and probably multiple aetiology and that they have their roots both in the genetic make-up of the individual and in the long term effects of environmental stresses. Among these stresses we must surely include dietary malnutrition, using the term in its broadest sense to include deficiency, excess or imbalance of nutrients' (Brock, I96r).

With this in mind, let us consider, for example, the commonest cause of repeated absence of older children from school. This is asthma, and asthma and the related 
disorder, vasomotor rhinitis, seem to be becoming commoner. If this is true, is it related to excess food intake? Macdonald (1962) has shown that Illingworth's (1939) idea that asthma was common in children whose birth weights had been high was, after all, not true, but how does the weight at I year old correlate with the incidence of asthma? There is a widespread impression that obese infants are more 'chesty'. To put the question on a more general basis, is our present fashionable statement that it is 'impossible to overfeed a healthy infant' likely to be accepted so facilely in ro or 20 years' time? Holt ( 1960 ) has said that we want children who are 'better, not just bigger' (see also Holt, I96r).

\section{Factors influencing a child's size}

The problem I wish you to consider now is that of the child nearing the age of I year, who is obese. When is a baby 'big'? Since weight for age is easily assessed, perhaps we may discuss the problem of the big baby in terms of weight. The simplest criterion is to say that the child is notably big when he is more than 2 SDs or more than $20 \%$ above the mean weight for age, or is above the $97^{\text {th }}$ percentile in weight. But we ought to make allowance for the child's height or length; a $6 \mathrm{ft} 4$ in. surgeon commander and his tall wife had a 6-month-old baby who weighed $24 \mathrm{lb}$ $(60 \%$ above mean weight) but yet was not obese, for he was a tall child. Not all babies heavy for their age are obese, but if a child is over $27 \mathrm{lb}(\mathrm{I} 2.25 \mathrm{~kg})$ at $\mathrm{I} 2$ months old his weight is sufficiently unusual to receive special study.

Thus the factor of genetic influences is introduced, for, in assessing the normality or otherwise of a person's body configuration, we should assess whether he approximates to the shape, his somatotype, that is normal for him. The influence of genetic factors is not always easy to assess. When one parent is fat, there is a $50 \%$ chance that a child will be fat; and when both are fat there is an $80 \%$ chance (Mayer, 1957 ). It is difficult to sort out genetic factors from, for example, family traditions and from compulsive eating. I do not think there are yet adequate longitudinal studies. Boys with four Italian grandparents are considerably bigger if they grow in Boston, USA instead of in Rome (H. Bourtiline-Young, to be published). Could this be due to a high early food intake, for, as we shall see in rats, a high early food intake imprints a large appetite for food, a situation possibly analogous to that producing the larger size of the foal of a Shetland $\times$ cart-horse cross born to cart-horse mares as compared with the reciprocal cross foals born to Shetland mares, the larger size of the foal born to the cart-horse mare being attributed by Walton \& Hammond (1938) to the three times larger placenta giving a better foetal nutrition?

Birth weight requires to be allowed for in assessing the expected size of any individual child. Illingworth, Harvey \& Gin (I949) showed that at all ages the weight at birth bore a well-marked and constant relationship to subsequent physical development. For instance, there was, in girls, a difference of I I.2 lb at the age of 7 years between the mean weight of children who weighed $9 \mathrm{lb} 9 \mathrm{oz}$ and over at birth and that of children who weighed $5 \mathrm{lb} 8 \mathrm{oz}$ or less. In animals the foetuses of illnourished dams are small, the nervous system suffering less than bone and bone less than muscle or fat (Wallace, I945-6). It may be that a high nutrition level in 
foetal life imprints a continuing larger appetite and hence larger food intake and greater adult size.

It is of interest that those infant animals that are larger at birth are also more differentiated, more developed anatomically; it is clearly an advantage to the newly born to be more mature at birth. It seems that in a number of ways the female foetus is always ahead of a male of the same gestational age, so that at birth the female child is a month more mature and has (or certainly has had in the past) a greater chance of survival. In animal breeding a great maturity at birth could be of considerable economic importance because $20 \%$ of lambs (in Australia) and $25 \%$ of pigs, largely the smaller piglets, die within the ist week after birth (Wolstenholme \& O'Connor, I96I).

\section{The lifelong effect of an early high food intake}

The normal weight curve in infancy. Wickes (1952) did a service by studying the weight curve of healthy infants as opposed to that of total populations of infants. He showed that among human infants with no abnormality of pregnancy, perinatal or postnatal health, high rates of gain in weight, e.g. I lb a week, are common in the early months. It may well be that in these rapidly growing healthy babies there is a rate of formation of tissue protein higher than is usually associated with the increased rate of gain in weight which follows an increased intake of milk when the gain is largely fat. Wickes's infants did not continue to gain at a rapid rate after the age of 6 months.

McCance and his collaborators (Lát, Widdowson \& McCance, I96I; see also Anonymous, I96I) have shown that young rats in small litters took more milk and grew more quickly than their sibs in larger groups and, what is more, the smalllitter rats went on eating more after weaning and were larger than usual at puberty although this was earlier than usual, and as adults were unusually large as well as unusually heavy. The early life experiences of these rats seem to have imprinted them with a continuing voracious appetite. Widdowson (I955) has said that fat women have fat babies and that they produce much milk and the babies grow big and have early puberties and become fat mothers. Is this genetic or due to imprinting?

The immediate effects of high intakes of various constituents of the child's food

If eating more food leads to being a large child at I year old, we may ask what are the individual effects of increased intake of various specific constituents of the diet. In clinical practice, when we increase a child's intake of a particular dietary constituent we shall sometimes cause a previously deficient intake to reach the needed or the optimum level; sometimes we shall be increasing the intake above what is the necessary or even above the optimum level for the child's well being. If a child receives an excess sometimes this is easily disposed of ; sometimes it is harmful.

Minerals. Increased calcium intake increases calcium retention, but it increases katabolic as well as anabolic processes and the increased breakdown may continue after the cessation of the raised calcium intake (Gerschoff, Legg \& Hegsted, I958; American Institute of Nutrition: Symposium on Effects of High Calcium Intakes, I959). 
In clinical practice, it is common for children to have some iron-deficiency anaemia, and increased iron given to infants and preschool children often raises their blood haemoglobin (Mackay, 1933). Giving extra iron is also thought to reduce the incidence of minor infections in childhood.

Vitamins. On a mixed diet an overall increased intake of food will lead to a higher intake of vitamins. If the child is sensitive to vitamin $D$ there is a possibility of hypercalcaemia. Bakwin ( 1961 ) has given a detailed consideration of the overuse of vitamins in children.

Protein. In the early months of life, particularly in prematurely born (immature) infants, nitrogen retention can be increased by high protein intake, but not after the age of 6 months. Some of the nitrogen retention in early weeks is intracellular storage of amino acids (Cusworth, Phansalkar, Roitman, Norton \& Snyderman, 1959). If the food intake is increased only after the age of 6 months, does any excess gain of weight only represent more fat being laid down? It seems that in general a growing animal given more protein to eat than usual will contain more nitrogen and less fat, that the nitrogen content of the fat-free tissue will not be greater, but that various organs will be larger, the increased size of the kidney being attributed to work hypertrophy from having to excrete more urea (Walter \& Addis, 1939). It has, however, been found that rats kept continuously on a low-protein diet did better in later life than rats who were, during growth, temporarily on a high-protein diet (McCay, Crowell \& Maynard, I935; Slonaker, 193I; Ross, 1959). To this problem I shall return (see pp. I32, I33).

Fat. The relation of the fat intake of adults to disease is much studied at present. The high incidence of atheroma in US Army soldiers killed in Korea (Enos, Holmes $\&$ Beyer, 1955) and the low incidence in underprivileged peoples is noted, as is also the fall in mortality due to coronary disorder in Scandinavian countries between 1939 and 1945 and the rise within a few years of the end of the war (Malmros, I950; Strom \& Jensen, 195I). It remains difficult, however, to believe that any arterial changes induced by excessive food intake in the ist year will have an effect 30 or 40 years later.

Calories. Some eat a lot and remain thin; some seem to grow big on an average intake. The heavier infant is usually longer and may be more advanced in development. But the infant is not mobile; he has fewer possibilities of disposing of excess calorie intake by increased activity and, if his intake is high, he will lay down more fat. This is the more likely to happen because the foods he is given are mostly concentrated. He can eat food so quickly that at each meal he takes in a lot before appetite begins to slacken.

\section{Some other factors}

The amount of food offered or even the amount of food taken is not the only criterion of nutrition. The large-scale experiment of studying what 1000 children ate by Widdowson (1947) showed that a high food intake was not particularly correlated with great weight or with rapid gain. 
Widdowson (I95I) has also shown that if children are not happy they may eat $20 \%$ more food without increasing their rate of growth.

\section{The later effect of being a fat child at $\mathrm{I}$ year old}

The year-old child who weighs $27 \mathrm{lb}$ seems to suffer little harm from being fat and he is likely to become a toddler of ordinary dimensions. But he has an increased liability to become fat in later childhood and adolescence and this is disadvantageous because it is associated with obesity in later adult life. Furthermore, among obese adults, the obesity of those who have a history of having been obese in childhood is less easy to treat. The association of obesity in middle age with various disorders, from cholecystitis to coronary disease, from diabetes mellitus to death, is well known.

\section{The long-term effects of early feeding in animals}

I now discuss some experimental results on which as a clinician I need advice. A high food intake shortens the life of mice with a genetic tendency to obesity, and limitation lengthens life (Lane \& Dickie, r958). A high-fat diet has worse effects than an isocaloric diet with more carbohydrate (Silverberg \& Silverberg, 1955). Growth retardation by limitation of food intake is associated with longer life (McCay et al. I935). Slonaker's ( I93 I) longest-lived rats had a diet with $14 \%$ protein. Retardation of growth during nursing or during the early postweaning period has a lasting dwarfing effect, the converse of the lastingly high appetite and increased growth when litters were small (Schultze, 1955; Jackson, 1936, 1937; van Dam-Bakker, De Groot \& Luyken, I958, all quoted by Ross, I959). It may be that a longer life is not worth having if it is obtained only by postponing puberty.

But the lower incidence in the growth-retarded rats of illness in later life should be of interest to doctors. Pulmonary disease, the major cause of death in rats, is greatly reduced in growth-retarded rats (McCay, 1952; Saxton \& Kimball, r94I). So is chronic nephrosis (Berg \& Harmison, I957) and periarteritis of the mesenteric vessels (Simms \& Berg, 1957). New growths appear later and less frequently in rats and mice on restricted calorie intake (see references in Ross, 1959) whereas high-fat diets promote more and earlier mammary tumours (Tannenbaum, I942). Against these observations one weighs the higher incidence of cirrhosis and of kwashiorkor in protein malnutrition of human children.

Ross (I959) reported studies on rooo rats on five different diets. Rats on lowprotein or low-carbohydrate diets remained young-looking longer. Tumours developed in $40 \%$ of rats alive after I year on a high-protein, high carbohydrate diet but only in $20 \%$ of those on the low-protein, high-sugar diet, $15 \%$ of those on the high-protein, low-carbohydrate diet and $2 \%$ of those on the low-protein, low-sugar diet.

Of the rats on the high-casein, high-sugar diet, $40 \%$ had cardiovascular disorders, severe anomalies occurring in $8 \%$ of this group but not in any animals of the other groups. Renal lesions were present in $70 \%$ of animals on the high-protein, highcarbohydrate diet, the incidence and severity being lower in other groups. On the other hand, rats in the low-protein, low-carbohydrate group were especially liable to fatal caecal impaction in the ist year of life. 
The life span of the control group of rats was longer than usual for experimental animals; it averaged 729 days with a mode at 780 days. The group on the lowprotein, high-carbohydrate diet had an average life span of 840 days (mode 900). The longest span was that of the rats on the high-protein, low-carbohydrate diet who averaged 925 days. The mean life span of the group on the low-protein, lowcarbohydrate diet was reduced by prevalence of caecal impaction in early life, but, of the animals who survived the age of 2 years, those in the low-protein, lowcarbohydrate group lasted longest. The old saying 'after 40 eat as little as you can' may prove to be true. We have still to discover if the rest of the saying is good advice, 'Up to 20 eat as much as you can; 20 to 40 eat as much as you like'.

\section{What is the clinician to do?}

We need to confirm the impression that obesity at I year old is correlated with obesity in later childhood and in adult life. But the evidence that this is so is enough for me to feel that I should try to help children not to be obese at I year old. We need to assess the advantages and disadvantages of a lavish food supply and of limitation of food intake. I am inclined to think that it is unwise to accustom the infant and child to a large protein intake. It is probably easier at any age to prevent obesity developing than it will be to treat it once it has been in existence for a time. There are differences between the state of 'static' obesity and of 'active' or developing obesity with high tolerance for carbohydrate and a tendency to hypoglycemia (Beaudoin, Van Itallie \& Mayer, 1952-3).

As we do not always know an individual's proper size and shape, we should try to determine it before being very rigorous about limiting size by dietary measures. Parnell (1962), in reference to dietary treatment of obesity in adults, has recalled the need to know the patient's own somatotype and to avoid trying to make him conform to an ideal shape which does not in fact apply to him. It seems wise to record visually the child's growth in length and head circumference as well as his weight, and to do so on a chart giving a wide range of variation in weight. If the child's weight appears to be diverging unduly above what is appropriate for his age and length, then his food intake may be reduced, not enough to arrest his growth but enough to cause his weight to return towards the average.

It will be wise to discuss food and fatness with the mother and father to obtain their ideas and feelings. They may be giving food to build up the child's strength or as reassuring evidence that they are not poor (Apley \& Mac Keith, I962). It may be that some group therapy will be needed to give the mother an inner incentive to keep on at her task.

\section{Conclusion}

In view of the experimental finding that 'Animals which had the highest growth rate had the lowest life expectancy and the highest incidence of age-associated diseases' (American Institute of Nutrition: Symposium on Protein Requirement and its Assessment in Man, 1959) the life-long effects of early dietary experiences deserve urgent further studies. 
Obesity in later infancy is associated with obesity in adult life and should therefore be avoided, for obesity in adult life is dangerous.

It is probably simpler to prevent developing gross obesity than to treat it. In prevention and in treatment a comprehensive approach is needed dealing with the feelings as well as the food intake of the child and his parents.

\section{REFERENCES}

American Institute of Nutrition: Symposium on Effects of High Calcium Intakes (I959). Fed. Proc. I8, 1075 .

American Institute of Nutrition: Symposium on Protein Requirement and its Assessment in Man (1959). Fed. Proc. 18, I I25.

Anonymous (196I). Brit. med.F. i, 45.

Apley, J. \& Mac Keith, R. (1962). The Child and His Symptoms. London: Churchill.

Bakwin, H. (I96I). F. Pediat. 59, I 54.

Beaudoin, R., Van Itallie, J. G. \& Mayer, J. (1952-3). F. clin. Nutr. I, 9 I.

Berg, B. N. \& Harmison, C. R. (1957). F. Geront. 12, 370.

Brock, J. F. (editor) (1961). Recent Advances in Human Nutrition. London: Churchill.

Cusworth, D. C., Phansalkar, S. V., Roitman, E., Norton, P. M. \& Snyderman, S. E. (I959). Fed. Proc. r8, 209.

Enos, W. F. Jr., Holmes, R. H. \& Beyer, J. (1955). F. Amer. med. Ass. 158, 92.

Gerschoff, S. N., Legg, M. A. \& Hegsted, D. M. (I958). F. Nutr. 64, 303.

Holt, L. E. Jr. (1960). Postgrad. Med. 27, 783 .

Holt, L. E. Jr. (1961). In Recent Advances in Human Nutrition, Chapter 24. [J. F. Brock, editor.] London: Churchill.

Illingworth, R. S. (1939). Arch. Dis. Childh. 14, I 21.

Illingworth, R. S., Harvey, C. C. \& Gin, S. Y. (1949). Lancet, ii, 598.

Lane, P. W. \& Dickie, M. J. (1958). F. Nutr. 64, 549.

Lát, J., Widdowson, E. M. \& McCance, R. A. (196r). Proc. roy. Soc. B, 153, 347.

McCay, C. M. (1952). In Cowdrey's Problems of Ageing : Biological and Medical Aspects, 3 rd ed., p. I 39. [A. I. Lansing, editor.] Baltimore: Williams and Wilkins.

McCay, C. M., Crowell, M. F. \& Maynard, L. A. (1935). Y. Nutr. 10, 63.

Macdonald, A. D. (1962). Develop. Med. Child Neurol. 4, 595.

Mackay, H. M. N. (1933). Arch. Dis. Childh. 8, 22 I.

Malmros, H. (1950). Acta med. scand. 138, Suppl. 246, p. I37.

Mayer, J. (1957). Bull. N.Y. Acad. Med. 33, 744.

Parnell, R. W. (1962). Med. News, no. 5, p. 8.

Ross, M. H. (1 959). Fed. Proc. 18, I I90.

Saxton, J. A. Jr. \& Kimball, G. C. (I94I). Arch. Path. (Lab. Med.) 32, 93 I.

Silverberg, M. \& Silverberg, R. (1955). Physiol. Rev. 35, 347.

Simms, H. S. \& Berg, B. N. (1957). F. Geront. 12, 244.

Slonaker, J. R. (193 I). Amer. F. Physiol. 98, 266.

Strom, A. \& Jensen, A. R. (I95I). Lancet, i, 126.

Tannenbaum, A. (1942). Cancer Res. 2, 468.

Wallace, L. R. (1945-6). \%. Physiol. 104, 34 P.

Walter, F. \& Addis, 'T. (1939). F. $\exp$. Med. 69, 467.

Walton, A. \& Hammond, J. (1938). Proc. roy. Soc. B, I25, 3 I I.

Wickes, I. G. (1952). Arch. Dis. Childh. 27, 449.

Widdowson, E. M. (1947). Spec. Rep. Ser. med. Res. Coun., Lond, no. 257.

Widdowson, E. M. (1951). Lancet, i, 13 6 .

Widdowson, E. M. (1955). Amer. F. clin. Nutr. 3, 391.

Wolstenholme, G. E. W. \& O'Connor, M. (editors) (1961). Ciba Foundation Symposium on Somatic Stability in the Newly Born. London: Churchill.

\section{The comparative merits of breast and bottle feeding}

$$
\text { By Mavis Gunther, University College Hospital, London, W.C.I }
$$

Detailed information about the composition and effects of a food, when available and even widely accepted, does not necessarily govern the choosing of that food. 